\title{
Roadside Planting in Ethiopia: Turning a Problem into an
}

\section{Opportunity}

\author{
Marta Agujetas Perez ${ }^{1 *}$, Fredu Nega Tegebu ${ }^{2} \&$ Frank van Steenbergen ${ }^{1}$ \\ ${ }^{1}$ MetaMeta Research, s-Hertogenbosch, The Netherlands \\ ${ }^{2}$ The Horn Economic and Social Policy Institute (HESPI), Addis Ababa, Ethiopia \\ *Marta Agujetas Perez, E-mail: marta@metameta.nl
}

\begin{abstract}
Roads have both positive and negative impacts in the areas surrounding them. With the expansion of roads growing at an inexorable speed in Ethiopia and all Sub-Saharan Africa, these impacts need to be well understood. A questionnaire was used to gather information on road-related impacts on the rural population. A total of 529 sample households were selected in Tigray, Northern Ethiopia. The three most common consequences cited by respondents in order of importance were dust, flooding and erosion. Close to $44 \%$ of the respondents said that the occurrence of dust has increased after construction of the road. The reduction of yield estimated by farmers ranges from $10 \%$ to $50 \%$. Close to $11 \%$ of the sample households faced decline in crop production and income due to dust lifted up from roads. The breakpoint for road dust occurred approximately at 200 to 280 meters from the road. Roadside plantations along rural roads have proven to mitigate road-related impacts and restore the ecological balance. When linked to rural development programs, roadside planting can create employment while generating a reliable source of income for rural communities.
\end{abstract}

\section{Keywords}

roads, dust, tree planting, employment, Ethiopia

\section{Introduction}

The road network in Ethiopia is rapidly expanding. Investment in road infrastructure is the largest and geographically most widely distributed investment in the country. The government formulated the Comprehensive Road Sector Development Program (RSDP) in 1997 to address the constraints the road sector faced for long. During the period of the RSDP until 2014, the government constructed around $72,971 \mathrm{~km}$ new additional roads of all type. In 1997 the total road network in Ethiopia was 26,550 km and reached $99,522 \mathrm{~km}$ in 2014. Ethiopia has a vision of joining middle-income countries by 2028 . To achieve this goal, the country needs to increase its road network to $201,750 \mathrm{~km}$ by 2028 . Road development is also a priority area in the African continent. The Programme for Infrastructure Development in Africa (PIDA) will cost around US\$360 billion between 2011 and 2040, being 37\% of these costs projected for transport infrastructure. Moreover, infrastructure spending in Sub-Saharan 
Africa is estimated to grow from US\$70 billion in 2014 to US\$180 billion per annum by 2025 (PwC, 2014). Worldwide, it is expected that the world will need to add nearly 25 million road lane-kilometres $(\mathrm{km})$ and 335000 rail track kilometres by 2050 (Dulac, 2013).

Not denying the positive effects of road construction such as access to health, education and markets (Buys et al., 2006) some negative impacts should not be ignored. Roads alter landscape features including the hydrology, sediment transportation, water and air quality, microclimate, wind and light adjacent to roadsides (Forman et al., 2003; Coffin, 2007). Therefore, the land area next to the road is often subject to multiple impacts mostly erosion, sedimentation, waterlogging and dust (Garcia-Landarte Puertas et al., 2014). This in turn has a negative effect on the local population whose cropland is reduced or damaged and health affected from the dust.

Roadside vegetation has the capacity to alleviate the social and environmental damage caused by roads. Trees, shrubs and grasses established by the road side contribute to soil formation by shedding dead leaves, increase water quality by reducing sediment flow, reduce erosion, serve as wind break and provide important pollinator habitat while improving people's health and protecting crops. Well-designed vegetation barriers can improve local air quality by trapping near-road dust (Morakinyo $\&$ Lam, 2015). Besides, the establishment of roadside vegetation is a labour intensive activity, and thus it has the added value of creating employment.

This paper presents a study carried out in two districts of Tigray region, Ethiopia. We first describe road-related environmental problems perceived by local communities residing next to the road. We then zoom-in the effect of dust on agriculture and health. Finally, we describe participatory roadside tree planting as a double-win solution.

\section{Method}

The data source for this section is drawn from a baseline survey conducted from April to May 2015. The baseline survey was conducted on two types of roads - feeder road and regional highways — in two woredas (districts) in the Tigray Regional State in northern Ethiopia. Four tabias - two connected by feeder roads (Were Abaye and Adi Kisandid) and the remaining two connected by regional highways (Hade Alga and Mai Quiha) - were selected for analysis. The Figure below shows the location of the study sites. 


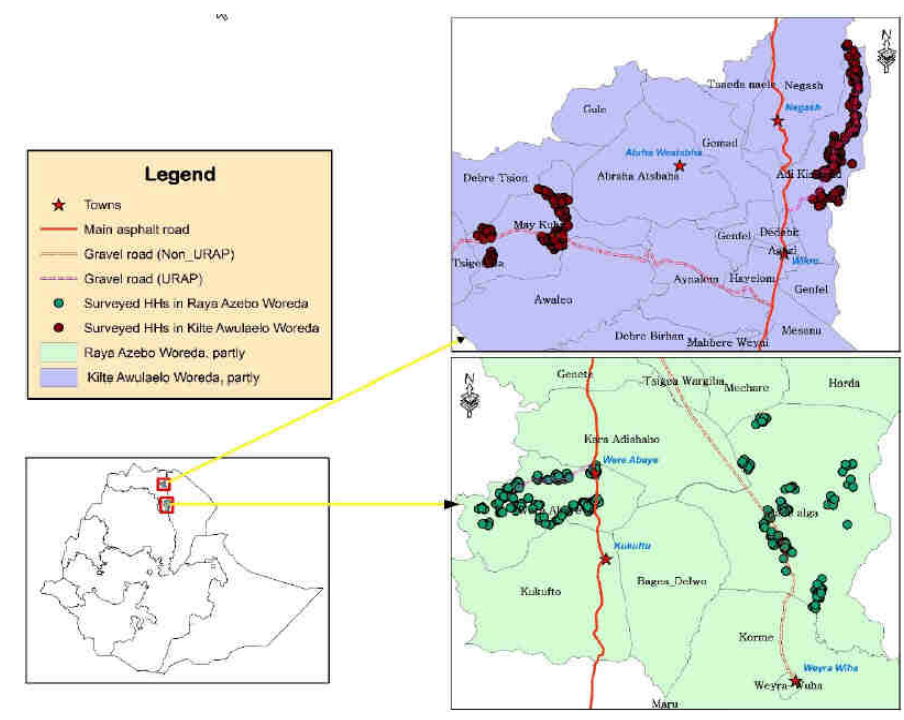

Figure 1. Location of Study Sites

A total of 529 sample households were selected from the four study tabias. Sample households were distributed proportionately to each tabia based on the number of resident households and in each tabia, the sample is further distributed to each sub-village locally called kushet. Once sample households are proportionately distributed to each kushet, simple random sampling was used to select sample households. A list of households was obtained from each kushet and sample households were selected at regular interval with a random start. The Table below shows distribution of sample households by tabia.

Table 1. Distribution of Sample Households

\begin{tabular}{lll}
\hline Tabia & Sample size & Percentage \\
\hline Adi Kisandid & 151 & 28.54 \\
Mai Quiha & 118 & 22.31 \\
Hade Alga & 124 & 23.44 \\
Were Abaye & 136 & 25.71 \\
Total & 529 & 100.00 \\
\hline
\end{tabular}

A multi-purpose questionnaire was used to gather information on a number of issues related to rural road development. This paper focuses on the information on effects of road on flooding, erosion, sediment deposition and occurrence of weeds and dust, with an emphasis on the effect of road dust on health and farm productivity.

Both descriptive and statistical analysis are used to summarize the influence of road dust. Tables and Figures are used for the descriptive analysis. For the statistical analysis on road dust effect zone, we build a generalized linear regression and a generalized linear piecewise regression models. We used the glm function for the regression. 


\section{Results}

Infrastructure investments especially related to rural road development facilitate access to markets for inputs such as fertilizers and improved seeds and enable farmers to sell their produce to nearby markets through a reduction in transport fare and time (Raballand et al., 2010). On the other hand, the lack of road network can lead to increased transaction costs in rural areas which results in limited market access for farmers (Key et al., 2000). In developing countries, transport cost constitutes more than half of the marketing costs (Fafchamps et al., 2005). Hence such roads are vital in improving agricultural productivity and raising living standards in poor rural areas (Gannon \& Liu, 1997).

Rural roads also allow farmers to achieve additional non-farm employment opportunities, leading to a rise in income and reduce rural poverty (Ali \& Pernia, 2003). Rural roads improve mobility which in turn facilitates access (Donnges, 1998). In Ethiopia, road infrastructure and the spread of extension services has contributed to growth and poverty reduction. Using Generalized Methods of Moments and controlling for household fixed effects, Dercon et al. (2008) found that access to all-weather roads reduces poverty by 6.9 percentage points and increases consumption growth by 16.3 percent in Ethiopia.

However, roads can also have unwanted consequences. When fertile land is used for road construction local communities can lose an important source of income. Moreover, roads can increase flooding, erosion, water logging, sediment deposition, and heavy dust. Unpaved roads provide a virtually unlimited source of dust. Considering that over 70\% of the road network in SSA (including Ethiopia) is still unpaved (Greening, 2011), the effects on the local population are enormous. Millions of communities on road sides are currently exposed to the negative effects of road dust and other impacts. Moreover, dust poses a safety hazard for road users due to reduced visibility caused by dust clouds (see for example Figure 2 below).

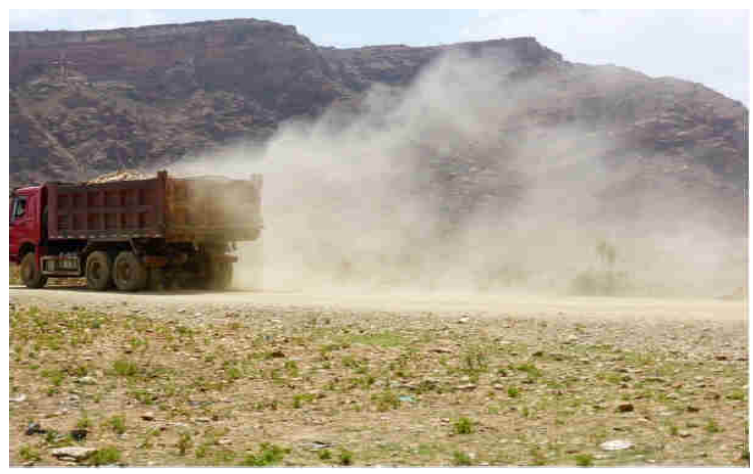

Figure 2. Dust Reducing Visibility along Roads in Tigray Region, Ethiopia

In the field survey, households were asked the perceived effects of roads on the local environment. Table 2 below summarizes the result. 
Table 2. Effects of Roads on Flooding, Erosion, Water Logging, Sediment Deposition and Dust

\begin{tabular}{|c|c|c|c|c|c|}
\hline \multirow[t]{2}{*}{ Effect of road } & \multirow[t]{2}{*}{$\begin{array}{l}\text { No. } \\
\text { observations }\end{array}$} & \multirow[t]{2}{*}{ Frequency } & \multirow[t]{2}{*}{ Percent } & \multicolumn{2}{|c|}{$\begin{array}{l}\text { Proportion of households whose } \\
\text { crop production is affected }\end{array}$} \\
\hline & & & & Frequency & Percent \\
\hline $\begin{array}{l}\text { Increased flooding } \\
\text { along road }\end{array}$ & 525 & 179 & 34 & 41 & 8 \\
\hline $\begin{array}{l}\text { Water logging } \\
\text { along road }\end{array}$ & 525 & 61 & 12 & 9 & 2 \\
\hline Erosion along road & 525 & 153 & 29 & 34 & 7 \\
\hline $\begin{array}{l}\text { Sediment } \\
\text { deposition along } \\
\text { road }\end{array}$ & 525 & 95 & 18 & 21 & 4 \\
\hline $\begin{array}{l}\text { Dust clouds along } \\
\text { road }\end{array}$ & 525 & 229 & 44 & 56 & 11 \\
\hline $\begin{array}{l}\text { Occurrence of } \\
\text { weeds along road }\end{array}$ & 525 & 47 & 10 & 8 & 2 \\
\hline
\end{tabular}

The three most common consequences cited by respondents in order of importance are dust, flooding and erosion. Close to $44 \%$ of the respondents said that the occurrence of dust has increased after construction of the road. The second impact reported by $34 \%$ of the respondents is flooding followed by erosion, where $29 \%$ said it has increased after construction of the road. The least common consequences of roads cited by respondents are sediment deposition, water logging and occurrence of weeds.

However, all households who reported consequences from road construction may not be directly affected by the problem. The last column of Table 2 indicates the frequency and percentage of households directly affected through reduction of production of crops and/or income as a result of road construction. Close to $11 \%$ of the sample households have faced decline in crop production and/or income due to dust lifted up from roads. Following dust, flooding and erosion are the other two factors that negatively affected crop production and/or income of nearly $8 \%$ and $7 \%$ of the sampled households respectively. The Figures above indicate that a significant proportion of the rural communities who live along unpaved roads are negatively affected by them.

Moreover, dust can also affect people's health. Road dust is composed by coarse particles that can worsen heart or lung-related conditions when inhaled through the nose and mouth (Greening, 2011). High levels of dust can cause skin irritations and diseases, eye irritations, shortness of breath, chronic obstructive airways disease, asthma, interstitial lung disease, lung fibrosis, lung emphysema and increased risk of lung and skin cancer (Krzyżanowski et al., 2005). The human body can handle 
particles larger than $10 \mu \mathrm{m}$, but for smaller particles it becomes more difficult for the body to block them (Nordstrom \& Hotta, 2004).

\subsection{Effects of Road Dust in Agricultural and Horticultural Production}

Dust can have a physical and chemical impact on crops, which can lead to yield reduction. Dust from unpaved roads deposits on the flowers of crops, impeding them to germinate and produce the fruit. Moreover, dust affects photosynthesis, respiration and transpiration and therefore interfere with plant growth (Leghari et al., 2013). Dust on plants can smother the leaves, block stomata and obstruct photosynthetic activities (Rahul \& Jain, 2014). Particulate deposition on plants reduces growth, yield, flowering, and reproduction (Saunders \& Godzik, 1986). The dust accumulation on leaf surfaces causes conditions similar to water stress, such as a reduction of stomata conductance, photosynthesis and transpiration and increased leaf temperature (Zia-Khan, 2015).

According to McCrea (1984), the major effects of road dust on agricultural and horticultural production are:

1) Reduced photosynthesis leading to loss of plant yield;

2) Increased pest and disease incidence causing yield losses and reduced quality of horticultural produce;

3) Dust contamination reducing fruit production and vegetable attractiveness;

4) Dust hindering the pollination of small seeded fruits by insects causing flower abortion and deformed fruit.

Dust cover on plants makes difficult for the plant to absorb sunlight through the leaf surfaces. This in turn causes a reduction in photosynthesis, decreasing plant growth and yield. This goes in line with the findings of the survey summarized in Table 3 . The reduction in photosynthesis can lead to a reduction in number of buds, a decrease on the size of fruits due to lack of carbohydrates, and lower the sugar content in fruits (McCrea, 1984). The yield reduction depends mostly on the thickness of dust cover and the type of plant. Thompson et al. (1984) conducted a study in Great Britain to understand the effects of roadside dust on photosynthesis and determined that photosynthesis was greatly reduced when leaves were covered with 5 to $10 \mathrm{~g}$ of dust per $\mathrm{m}^{2}$ of leaf surface.

To understand the impact of the road dust on the productivity of farm-land, communities in the study area were asked to give an estimation of the impact of road dust on their agricultural production. The reduction of yield, as estimated by farmers, ranges from less than 10 percent to 50 percent. Table 3 summarizes the reduction in crop production due to road dust.

Table 3. Effects of Road Dust on Crop Production and Income

\begin{tabular}{lll}
\hline Decrease in crop production & No. of households & percent \\
\hline Less than 10 percent & 14 & 29 \\
Between 10 to 30 percent & 27 & 55 \\
\hline
\end{tabular}




Between 30 to 50 percent $\quad 8 \quad 16$

Although it is difficult to exactly quantify the loss of crop production due to road dust, Table 3 presents the local communities' perception of the amount of loss in crop production associated with road dust. Among the households affected by road dust, the majority (55\%) believe that road dust is causing 10 to 30 percent reduction of their crop production. Few responders (16\%) even account the loss in crop production due to road dust to 30 to 50 percent of their harvest. This is also reflected by previous research. For instance, a study conducted on cotton plants in China showed $28 \%$ reduction in yield due to dust deposition (Zia-Khan, 2015). Experiments with cement dust on Brassica campestris L. in India also showed a reduction in yield, growth and photosynthetic pigments (Shukla et al., 1990). Results from experiments in Iraq showed that the length of spike of Triticum aestivum and pod length of Pisum sativum were significantly decreased by spraying dust as compared with control, which would in turn lead to lower yields (Rahman, 2015).

The influence of road dust on yields can have severe consequences in the livelihoods of roadside communities if mitigation measures are not put in place. Subsistence agriculture is the main livelihood activity in the study area. Therefore, a reduction on crop yield can have tragic impact in poor households, some of them already dependent on food aid.

\subsection{Road Dust Influence Zone}

To identify the influence zone of road dust (i.e., the distance where the effects of road dust are felt by the community) we used linear regression and piecewise regression models. The objective was to identify whether a threshold-type relationship between distance to road and effects of road dust can be established.

To quantify the magnitude of the effect of the road on dust, we compared the Akaike's Information Criterion (AIC) values for the simple linear model, the piecewise regression model, and of an additional simple log linear model, which was identical to the first, except that we log-transformed distance to road. In the piecewise and linear regression models, besides distance to road we included other household characteristics, income and some asset variables that could be associated with a households' susceptibility to road dust effects.

Table 4 shows regression results. We tested the significance of the slope of the relationship between distance to road and the response in the linear models. For the piecewise regression model, we tested the significance of the slope of the relationship between distance to the road before the breakpoint, and the significance of the "difference in slope parameter". We compared overall model fit of the linear and piecewise regression models for each response using the Akaike Information Criteria (AIC) value.

Table 4. Relationship between Road Dust and Distance to Road as Measured by Linear, Log-Linear and Piecewise Regressions 


\begin{tabular}{|c|c|c|c|c|c|c|}
\hline $\begin{array}{l}\text { Type of } \\
\text { model }\end{array}$ & AIC & $\begin{array}{l}\text { Slope: } \\
\text { Distance to } \\
\text { road }\end{array}$ & $\begin{array}{l}\text { Slope: } \\
\log (\text { distance } \\
\text { to road) }\end{array}$ & $\begin{array}{l}\text { Breakpoint } \\
(\mathbf{k m})\end{array}$ & $\begin{array}{l}\text { Slope before } \\
\text { breakpoint }\end{array}$ & $\begin{array}{l}\text { Difference in } \\
\text { slope } \\
\text { parameter }\end{array}$ \\
\hline Simple & 0.565338 & -0.0022705 & & & & \\
\hline $\begin{array}{l}\text { linear } \\
\text { model }\end{array}$ & 7 & $\begin{array}{l} \pm 0.00048^{* *} \\
*\end{array}$ & & & & \\
\hline $\log$ & 0.562908 & & -0.7454171 & & & \\
\hline linear & & & $\pm 0.10407 * *$ & & & \\
\hline model & & & $*$ & & & \\
\hline Piecewise & 0.554017 & & & 0.2380927 & -8.35692 & 7.097131 \\
\hline regressio & & & & $\pm 0.042999 * *$ & $\pm 3.104761^{* *}$ & $\pm 3.138872 * *$ \\
\hline $\mathbf{n}$ & & & & $*$ & $*$ & $*$ \\
\hline
\end{tabular}

Table 4 indicates that the difference in slope parameter is statistically significant at $1 \%$ significant level indicating that the piecewise regression model gave at least as good a fit to the data as the linear models. In fact, looking at the AIC, the piecewise regression model is the best fit model compared to the linear regression models.

The breakpoint for road dust occurred approximately at 200 to 280 meters from the road. Column six of Table 4 indicates a statistically significant relationship with distance to the road up to the threshold distance. This means that the effect of dust that is lifted up when cars especially heavy trucks use the rural roads in the study sites is typically felt in a radius of 200 to 280 meters from both sides of the road.

Following the statistical breakpoint, the road dust effect zone is mapped for each of the four study sites.

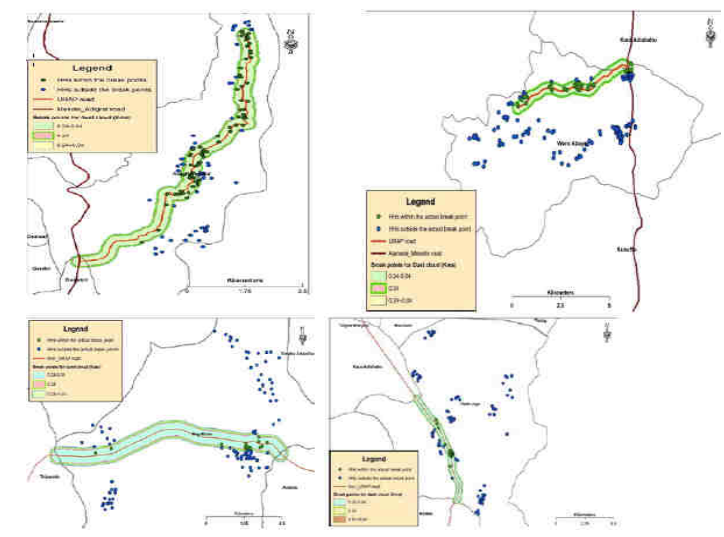

Figures 3. Road Dust Influence Zone Map in the Study Areas: Adi Kisandid, Were Abaye, May Kuha and Hade Alga 
Depending on the distance of households from the road, the proportion of households affected by road dust (i.e., households that fall in the effect zone of road dust) differs from tabia to tabia. In tabias of Adi Kisandid and Were Abaye, where most households are relatively close to the road, a significant proportion of the households fall within the zone of influence of the road dust. On the other hand, in Mai Kuha and Hade Alga the proportion of households residing close to the road is small.

According to Morakinyo and Lam (2015) the distance to maximum concentration of road pollutants depends on wind strength and direction and it varies between 2 to 8 meters. The farthest distance reached by pollutants is reached when there was a perpendicular wind direction $\left(90^{\circ}\right)$. The pollutant reduction efficiency increases with increasing distance from the road.

\section{Roadside Planting: Turning a Problem into an Opportunity}

The previous sections have described some effects of roads on the environment, health and agricultural production. In this section we describe how to turn these problems in to a solution by planting trees, shrubs and grasses along roads. These are also known as road-side vegetation barriers (Morakinyo \& Lam, 2015). Roadside planting provides a wide array of socio-economic and ecological benefits (Xu et al., 2006; Maher et al., 2013; Brantley et al., 2014; Neema \& Jahan, 2014). Plantations of trees and shrubs along rural roads have the potential to tackle most of the negative impacts caused by rural roads. The leaves of the trees have the ability to trap a large part of dust and particulate matter generated by traffic. Al-Dabbous and Kumar (2014) showed a decreased of 36\% of deposited particles in an area adjacent to the road due to the presence of a vegetation barrier. Moreover, vegetation can improve water quality by trapping sediments that would otherwise flow to adjacent land or streams. Vegetation can also increase road stability by lowering local water Tables that may affect the road formation and pavement. In addition, vegetation can reduce flooding by slowing and absorbing road run-off. However, the effect trees have on the concentration of dust particles nearby roads depends on wind direction (Tong et al., 2015). Table 5 depicts ecological and socio-economic benefits derived from roadside plantations.

Table 5. Ecological and Socio-Economic Benefits of Roadside Plantations

\begin{tabular}{ll}
\hline Ecological benefits & Socio-economic benefits \\
\hline Contribution to soil formation by & Improve people's health by reducing dust \\
shedding dead leaves & \\
Increase water quality by & Increase yields in adjacent farmland \\
reducing sediment flow & \\
Reduced erosion by holding soil & Increased employment \\
in place & \\
Flood control: slow and absorb & Increasing road stability: vegetation helps to lower local water \\
\hline
\end{tabular}


road run-off

Wind break

Carbon dioxide sequestration

Defence against invasive weeds

Provide important pollinator

habitat

Source: (Forman et al., 2003; Xu et al., 2006; Maher et al., 2013).

The road-effect zone concept describes the impact of influences such as noise, vibration, light and dust associated with roads and traffic on the surrounding area (Jones et al., 2015). As shown on Table 4, road dust on our study sites influences the area on a radius of 200 to 280 meters on both sides of the road. We argue that roadside plantations can help mitigate the road-effect zone by providing a barrier to dust and other annoyances generated from rural roads. Trees and vegetation, also known as porous barriers, affect pollutants and dust deposition and provide filtering effects (Gallagher et al., 2015).

The ability of a plantation to trap dust depends on a combination of tree and shrub species characteristics such as height, density and longevity. Height will influence the size of the protected area, with taller plantations protecting larger areas. Density influences the extent of downwind protection. As the trees mature, density near the ground will have to be provided by thick growing shrub species. Spacing recommendations between trees, as well as between rows, varies depending on the species planted and mature crown-size. When planning a plantation next to farmland using an ox-plough, consideration should be given to leaving enough space for the ploughing manoeuvres.

The type and location of the roadside plantation depends upon the width of the space available and the potential for management problems and safety hazards in the future. A minimum clear zone of 3 meter from the road edge is suggested for avoiding any road accidents. Large sized trees (15-30 $\mathrm{m}$ high) are generally recommended for planting along major roads and expressways with planting verge greater than $3.0 \mathrm{~m}$ in width. Medium sized trees (5-15 m high) are normally recommended for planting at major roads and some minor roads with planting verges between $1.5 \mathrm{~m}$ to $3.0 \mathrm{~m}$ in width. Small sized trees (less than $10 \mathrm{~m}$ ) are generally suggested for planting at minor roads with narrow/restricted planting verges less than $1.6 \mathrm{~m}$ in width.

To increase the filtering effects, roadside plantations must have some porosity to allow the wind pass through. The interference by trees makes the air move slower and become turbulent. This allows the vegetation to trap dust particles. High porosity vegetation barriers are penetrated by wind, allowing deposition of pollutants, while low porosity forces air streams to pass above it (Tiwary et al., 2005). Ideally, roadside plantations should be composed by a combination of grasses, shrubs and trees to trap the dust more efficiently. The grasses will also prevent water erosion and act as a filter before the water from the road reaches the farmland. Weber et al. (2014) found that hairy leaves increase deposition.

In a study carried out by Tong et al. (2016) six different roadside vegetation barrier designs were tested to identify bets options for pollution mitigation. Out of the six design options, two of them were Published by SCHOLINK INC 
identified as potentially viable: 1) a wide vegetation barrier with high Leaf Area Density, and 2) vegetation-solid barrier combinations, i.e., planting trees next to a solid barrier (Figure 4).
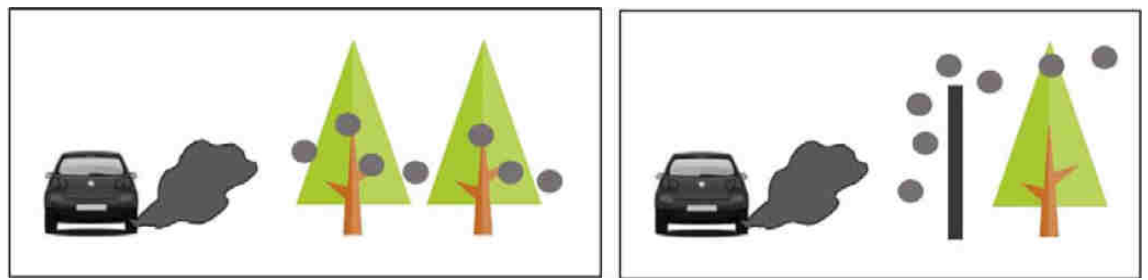

Figure 4. Potential Roadside Vegetation Barriers to Mitigate Pollution and Dust

Source: Tong et al., 2016.

A higher volume of vegetation barrier can lead to increased filtration or collection of particulates (Morakynio \& Lam, 2015). Locating the vegetation barrier further from the source of dust helps to improve dispersion of particles. The thickness (more than the height) of vegetation barrier is as important as closeness to source for improvement of mass removal. On the other hand, deposition of particles increases when higher volume of trees and shrubs is placed closer to the source region.

Sun direction and the effect of shade in farmland must be always considered when designing roadside plantations. Figure 5 shows an example from Pakistan. The trees on the left side of the picture were lopped by the farmers on the roadside because the shade was reducing the crop yields.

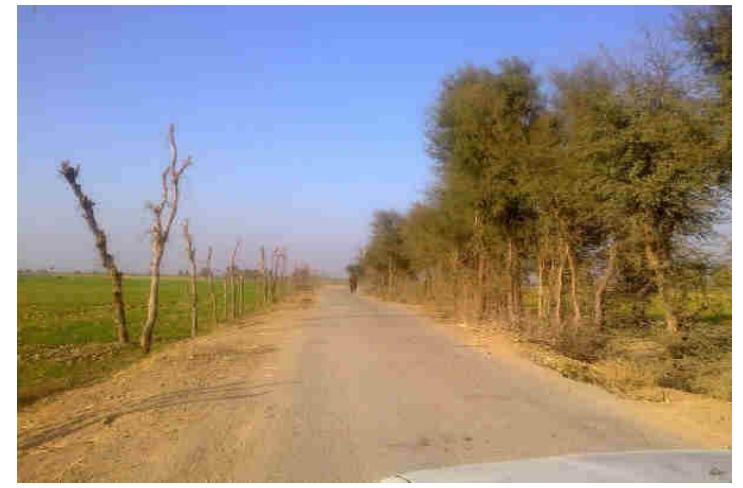

Figure 5. Roadside Trees Lopped by Farmers because of Reduction in Yields

In free-grazing areas and places subject to damage, fencing will be necessary. Social fencing is sometimes considered an alternative to a physical fence (Siyag, 2014). If all the residents of the area agree to keep their cattle off the plantation, and if there is no risk of cattle from other villages encroaching upon it, it is possible to establish the plantation without a physical fence. However, social fencing is particularly challenging in roadside plantations as these plantations often cross several districts. When selecting fencing materials, it is preferable to use materials that allow sufficient sunlight for photosynthesis. Stone or brick fences are not advisable since they block the sunlight, impeding plant 
growth.

Trees also need to be pruned to remove dangerous overhanging branches or to prevent lower branches from blocking a pathway or impeding visibility. Moreover, special arrangements can be made with farmers to cultivate the slopes of embankments for planting crops that provide groundcover and enrich the soil such as beans.

A very important factor to consider when designing road side plantations is road safety. Trees can cause accidents and special mitigation measures are necessary at certain speeds to avoid them. Table 6 shows safety mitigation measures depending on the speed zone.

\section{Table 6. Road Safety Mitigation Measures}

\begin{tabular}{|c|c|c|}
\hline $\begin{array}{l}\text { Speed } \\
\text { zone }\end{array}$ & \multicolumn{2}{|c|}{ Road safety mitigation method } \\
\hline $40 \mathrm{~km} / \mathrm{h}$ & \multicolumn{2}{|c|}{$\begin{array}{l}\text { The impact force is unlikely to exceed human tolerances, so no specific mitigation is } \\
\text { needed. }\end{array}$} \\
\hline $50 \mathrm{~km} / \mathrm{h}$ & \multicolumn{2}{|c|}{$\begin{array}{l}\text { A minimum lateral distance from road edge of } 1 \mathrm{~m} \text { should be maintained to reduce } \\
\text { incidental interaction between vehicles and trees. }\end{array}$} \\
\hline \multirow[t]{5}{*}{$60 \mathrm{~km} / \mathrm{h}$} & - Intersections & $\begin{array}{l}\text { at least } 10 \mathrm{~m} \text { beyond intersection on the approach and departure } \\
\text { side }\end{array}$ \\
\hline & - Driveways & at least $3 \mathrm{~m}$ between driveway and tree \\
\hline & - Lane & $3.6 \mathrm{~m}$ lateral distance from road edge \\
\hline & locations & \\
\hline & • Curves & $\begin{array}{l}3.6 \mathrm{~m} \text { lateral distance from road edge for gentle curves; barrier } \\
\text { for moderate/tight curves }\end{array}$ \\
\hline $70-100$ & \multicolumn{2}{|c|}{ The impact force is highly likely to exceed human tolerances } \\
\hline $\mathrm{km} / \mathrm{h}$ & \multicolumn{2}{|c|}{$\begin{array}{l}\text { Safety barriers are the most appropriate mitigation (wire rope safety barrier, guard rail or } \\
\text { other approved safety barrier that is suitable in high speed environments) }\end{array}$} \\
\hline
\end{tabular}

Source: VicRoads Tree Planting Policy, 2015.

\subsection{Road Side Planting and Employment Generation: Examples from Ethiopia}

Besides providing a barrier to dust and other road side effects, road side tree planting can have a number of added advantages. Roadside tree planting is a labour intensive activity (Table 7). It has the potential to provide wage employment and create productive assets for the rural poor. For example, on the asphalt road from Addis Ababa to Woliso a road stretch of $14 \mathrm{Km}$ (on both sides) was covered (Figure 6). The trees planted were Grevillea robusta, Schinus molle, Cupressus lusitanica and Olea africana. For this plantation, 37 people were hired temporarily for pitting and planting (three months during the rainy season), while 13 people were hired on a permanent basis for one year to conduct the 
maintenance works. The daily salary for each person was 70 ETB ( \pm 3 USD). Labourers were selected from towns close to the road side project. According to the contractor, it was too complicated to employ farmers with land bordering the road, as it would be hard to screen them and their houses might be far. A significant amount of employment was also generated for fencing preparation, wood supply and transportation.

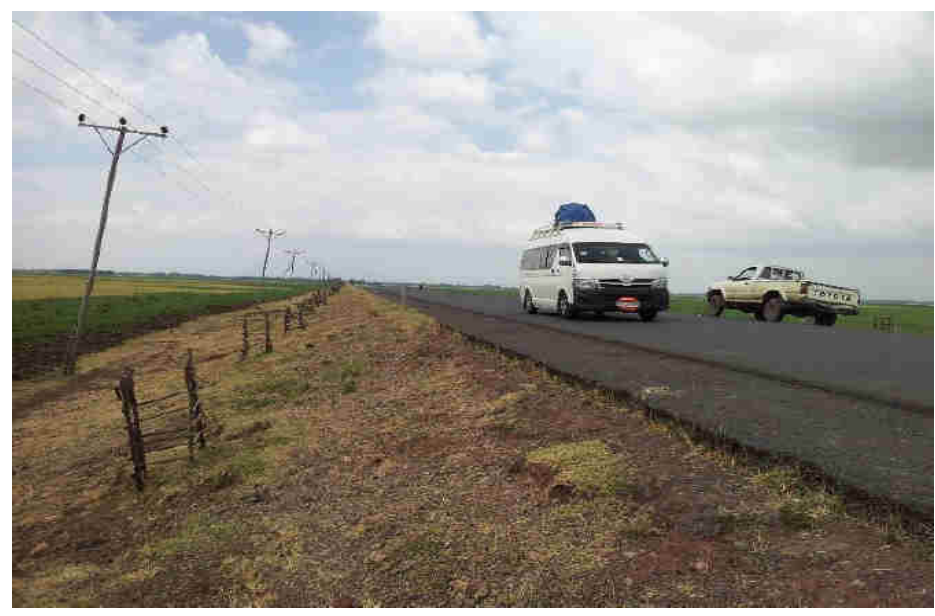

Figure 6. Roadside Plantation along Addis Ababa—Woliso Road

Examples of roadside tree planting in Ethiopia are scarce, although the practice in expanding. In the town of Wukro, in Northern Ethiopia, a participatory street-side planting project was recently implemented. The main objective was to create employment in the town. Currently, there are 20 people employed for maintenance. Beneficiaries were identified from the poorest families through the local administration. The gardeners and guards will be employed during five years, earning a monthly salary of ETB 750 (USD 35). This project has proven to be very successful with high tree survival rate.

Table 7. Employment Generating Activities Related to Roadside Tree Planting

\begin{tabular}{ll}
\hline Employment generating activities from roadside planting & Type of employment \\
\hline Pitting & Temporary: \pm 15 pits/person/day \\
Planting & Temporary: \pm 50 plants/person/day \\
Maintenance & Permanent $3-5$ years \\
Preparation of fencing materials & Temporary \\
Nursery site & Permanent/temporary \\
Wood suppliers for fencing & Temporary \\
Transportation of fencing and other materials & Temporary \\
\hline
\end{tabular}

Roadside planting provides opportunities for employment from nursery operations to plantation 
maintenance and management. For example, land preparation and planting can be carried out by unemployed people in the community who can be paid as daily labourers. Since many areas in Ethiopia are still under free-grazing, guards will be needed in many cases. These guards can be selected from groups who are in need of employment, such as elderly people, women and landless youngsters. In addition, these plantations are often irrigated plantations. The number of watering operations required will depend upon the species and this task could be also carried out by unemployed members of the community. It is crucial to involve the local administration on the selection of beneficiaries, as they usually have identified the most vulnerable groups and have their own mechanisms and criteria for selection. In Ethiopia, beneficiaries from development interventions are usually selected by a committee formed by representatives from the local administration (chairman, vice-chairman and development agents) and members from the youth, women and farmers' association.

Roadside plantations can also be handed over to cooperatives of women or landless people. Authorities can provide right to usufruct to cooperatives. These cooperatives can be supported by the government or alternatively ask for micro-credit. These groups can then plant multipurpose trees that give a reliable economic return such as fruit trees, Moringa oleifera or trees used to produce local beverages. A good alternative is planting trees and shrubs that attract pollinators, especially bees, and advice cooperatives to start bee keeping to produce high quality honey.

Moreover, the employment opportunities to be created through roadside tree planting can also be useful to compensate households who lost production assets (mainly land) to road construction. Although in many cases households are compensated for the land lost for highway road construction, land lost for feeder road construction under the Universal Rural Access Program (URRAP) in Ethiopia is not compensated. For example, in their baseline survey report, Fredu and Edris (2016) documented that about $14 \%$ of the respondents in the study sites reported that they have permanently lost farm land for road construction. Of these households, the majority (77\%) were not compensated for their lost land. Thus, to compensate for lost productive assets, households who lost land for road construction can be given priority to get employment opportunity on road side tree planting.

\section{Conclusion and Recommendations}

Roads alter the landscape around them and can be the cause of disturbance to the communities living around them. Research along three rural roads in Tigray, Ethiopia, has found several negative effects of roads on the local population and environment. The most prominent effects highlighted by this research are - by order of magnitude-road dust affecting cropland, flooding of adjacent land and erosion. Out of 525 respondents, $44 \%$ reported being affected by the road dust. The effect is typically felt in a radius of 200 to 280 meters from both sides of the road. Since agriculture is the main income generating activity in the area, mitigation measures should be put in place to alleviate this problem.

Roadside planting presents a solid solution to buffer the environmental damage from roads by trapping dust and reducing erosion, flooding and sedimentation. When coupled with rural development 
programs, large implementation of roadside planting will create wage employment among the rural poor. By selecting species of commercial importance roadside plantations will create productive assets. Special programs should be designed to target unemployed members of the community to benefit from the employment and the assets created.

The government of Ethiopia has one of the largest rural safety net programs in Africa. In 2005 a Productive Safety Net Program (PSNP) was launched in Ethiopia. It marked a shift from a relief oriented emergency system to a productive and development oriented safety net. Since its launch, the PSNP has been one of the Ethiopian governments' main programs to address poverty and food insecurity. In 2015, the government launched phase 4 of the PSNP.

With the current and projected expansion of the road network in Africa, the potential to systematically incorporate roadside planting is huge. For larger implementation and sustainably carrying out road side tree planting activities, it is highly recommended and advisable to relate the activity to existing government and non-government development programs carried out in the rural areas. The rural road side tree planting activities can be considered as part of the public work programs and it can thus be related for instance to the PSNP. In addition, roadside planting can be linked to private initiatives such as micro-credit organizations. Since the land adjacent to the road often belongs to the government, right to usufruct could be given to individuals or cooperatives who could then economically benefit from the plantation.

\section{Acknowledgments}

The support of NWO (Netherlands Scientific Council) under the program "Feeder road development for inclusive productive employment" in preparing this paper is acknowledged as well as the Global Resilience Partnership Program "Connecting Roads, Water and Livelihoods for Resilience". All the collaborating institutions mainly Tigray Bureau of Agriculture and Rural Development, Ethiopian Roads Authority, Amhara Bureau of Agriculture and St. Mary's College are highly acknowledged for their relentless support.

\section{References}

Al-Dabbous, A. N., \& Kumar, P. (2014). The influence of roadside vegetation barriers on airborne nanoparticles and pedestrians exposure under varying wind conditions. Atmospheric Environment, 90, 113-124.

Ali, I., \& Pernia, E. M. (2003). Infrastructure and Poverty Reduction-What is the Connection? ERD Policy Brief Series. Economics and Research Department, 13.

Brantley, H. L., Hagler, G. S. P., Deshmukh, \& Baldauf, R. (2014). Field assessment of the effects of roadside vegetation on near-road black carbon and particulate matter. Science of the Total Environment, 468, 120-129.

Buys, U. P., Deichmann, U., \& Wheeler, D. (2006). Road network upgrading and overland trade 
expansion in sub-Saharan Africa. Washington, DC: World Bank.

Coffin, A. W. (2007). From roadkill to road ecology: A review of the ecological effects of roads. Journal of Transport Geography, 15, 396-406.

Dercon, S., Gilligan, D. O. J., Hoddinott, \& Tassew, W. (2008). The impact of agricultural extension and roads on poverty and consumption growth in fifteen Ethiopian villages. IFPRI Discussion Paper, 00840.

Donnges, C. (1998). Rural access and employment: The Laos experience. ILO Employment Intensive Infrastructure Programmes: Rural Accessibility Technical Paper (RATP NO: 4).

Dulac, J. (2013). Global land transport infrastructure requirements: Estimating road and railway infrastructure capacity and costs to 2050. International Energy Agency. France.

Fafchamps, M. B., Minten, G., \& Eleni. (2005). Increasing returns and market efficiency in agricultural trade. Journal of Development Economics, 78(2), 406-442.

Forman, R. T. T. (2003). Road ecology: Science and Solutions. Washington, DC: Island Press.

Fredu, N., \& Edris, H. (2016). Quantifying the road influence zone on socio-economic development in rural Tigray, Ethiopia. HESPI Working Paper No. 3.

Gallagher, J., Baldauf, R., Fuller, C. H., Kumar, P., Gill, L. W., \& McNabola, A. (2015). Passive methods for improving air quality in the built environment: A review of porous and solid barriers. Atmospheric Environment, 120, 61-70.

Gannon, C., \& Liu, Z. (1997). Poverty and Transport. TWU discussion papers, TWU-30, World Bank, Washington, DC.

Garcia-Landarte Puertas, D. K., Woldearegay, L., Mehta, M., van Beusekom, M., Agujetas, \& F. van Steenbergen. (2014). Roads for water: The unused potential. Waterlines, 33, 120-138.

Gebremedhin, B., \& Swinton, S. M. (2000). Reconciling food-for-work project feasibility with food aid targeting in Tigray, Ethiopia. Food Policy, 26(1), 85-95.

Greening, T. (2011). Quantifying the impacts of vehicle-generated dust: A comprehensive approach. Transport Research Support Program. Washington DC: World Bank.

Jones, D. N. L., Bernede, A. R. F., Bond, C., Dexter, \& Strong, C. L. (2015). Dust as a contributor to the road-effect zone: A case study from a minor forest road in Australia. Australasian Journal of Environmental Management, 1-14.

Key, N., A. de Janvry, \& Sadoulet, E. (2000). Transaction Costs and Agricultural Household Supply Response. American Journal of Agricultural Economics, 82(2), 245-259.

Krzyżanowski, M. B., Kuna-Dibbert, \& Schneider, J. (2005). Health effects of transport-related air pollution. WHO Regional Office, Europe.

Leghari, S. K., Zaid, M. A., Sarangzai, A. A., Faheen, M., \& Ali, W. (2013). Effect of road side dust pollution on the growth and total chlorophyll content in Vitis vinifera L. (graps). African Journal of Biotechnology, 13(11), 1237-1240.

Maher, B. A., Ahmed, I. A. M., Davison, B., Karloukovski, V., \& Clarke, R. (2013). Impact of roadside 
tree lines on indoor concentrations of traffic-derived particulate matter. Environmental Science \& Technology, 47, 13737-13744.

McCrea, P. R. (1984). An Assessment of the Effects of Road Dust on Agricultural Production Systems. Lincoln College, New Zealand: Agricultural Economics Research Unit (Research Report No 156).

Neema, N. M., \& Jahan, J. (2014). An innovative approach to mitigate vehicular emission through roadside greeneries: A case study on arterial roads of Dhaka city. Journal of Data Analysis and Information Processing, 2.

Nordstrom, K. F., \& Hotta, S. (2004). Wind erosion in the USA: A review of problems, solutions and prospects. Geoderma, 121, 157-167.

Pricewaterhouse Coopers. (2014). Trends, challenges and future outlook: Capital projects and infrastructure in East Africa, Southern Africa and West Africa. Retrieved from http://www.pwc.com/ng/en/assets/pdf/capital-projects-and-infrastructure-trends-challenges-and-fu ture-outlook.pdf

Raballand, G., Macchi, P., \& Petracco, C. (2010). Rural road investment efficiency: Lessons from Burkina Faso, Cameroon, and Uganda. Washington, DC: World Bank.

Rahman, J. K. (2015). Response of Two Crop plants to Dust Deposition. Journal of Pure and Applied Sciences, 27(2), 1-6.

Rahul, J., \& Jain, M. K. (2014). An Investigation in to the Impact of Particulate Matter on Vegetation along the National Highway: A Review. Research Journal of Environmental Sciences, 8(7), 356.

Saunders, P. J. W., \& Godzik, S. (1986). Terrestrial vegetation-air pollutant interactions: Non-gaseous air pollutants. In A. H. Legge, \& S. V. Krupa (Eds.), Air Pollutants and Their Effects on the Terrestrial Ecosystem. Advances in Environmental Science and Technology (Vol. 18, pp. 389-394). Wiley, New York, USA.

Shukla, J., Pandey, V., Singh, S. N., Yunus, N., Singh, \& Ahmad, K. J. (1990). Effect of cement dust on the growth and yield of Brassica campestris L. Environmental Pollution, 66, 81-88.

Siyag, P. R. (2014). Afforestation, Reforestation and Forest Restoration in Arid and Semi-arid Tropics: A Manual of Technology \& Management. Springer Science \& Business Media.

Thompson, J. R., Mueller, P. W., Fluckiger, W., \& Rutter, A. J. (1984). The effect of dust on photosynthesis and its significance for roadside plants. Environmental Pollution Series, 34, 171-190.

Tiwary, A., Morvan, H. P., \& Colls, J. J. (2005). Modelling the size-dependent collection efficiency of hedgerows for ambient aerosols.

Tong, Z., Whitlow, T. H., MacRae, P. F., Landers, A. J., \& Harada, Y. (2016). Quantifying the effect of vegetation on near-road air quality using brief campaigns. Environmental Pollution, 201, 141-149.

Weber, F., Kowarik, I., \& Saeumel, I. (2014). Herbaceous plants as filters: Immobilization of particulates along urban street corridors. Environ. Pollut, 186, 234-240.

Xu, X. K., Zhang, Y., Kong, J., Chen, \& Yu, B. (2006). Effectiveness of erosion control measures along 114

Published by SCHOLINK INC. 
the Qinghai-Tibet plateau highway, Tibetan plateau, China. Transportation Research Part D: Transport and Environment, 11, 302-309.

Zia-Khan, S., Spreer, W., Pengnian, Y., Zhao, X., Othmanli, H., He, X., \& Müller, J. (2014). Effect of dust deposition on stomatal conductance and leaf temperature of cotton in northwest China. Water, 7, 116-131. 